\title{
Confirmatory Factor Analysis untuk Mengetahui Pemanfaatan Multimedia Learning \\ pada Perguruan Tinggi Swasta di Kota Semarang
}

\author{
Achmad Solechan \\ Program Studi Sistem Informasi \\ STMIK ProVisi Semarang \\ Semarang \\ achmad.solechan.semarang@gmail.com
}

\author{
Fitro Nur Hakim \\ Program Studi Teknik Informatika \\ STMIK ProVisi Semarang \\ Semarang \\ masfitro@gmail.com
}

\begin{abstract}
Dominant indicator of the use of multimedia in learning needs to be studied using the Confirmatory Factor Analysis. This study aims to determine the most dominant factor affecting the use of multimedia in learning, this study uses the Technology Acceptance Modelling theory. This study uses the technique of Judgment Sampling Area or a sampling technique that is based on the determination of the research area. Determination of the study area are four private universities in Semarang, namely USM, Udinus, STMIK Provisi and Unisbank, so the overall number of respondents as many as 200 students. This study shows that: 1-the greatest contribution value of the Perceived Usefulness latent variable that is multimedia learning increase the effectiveness of learning in the classroom, 2-the greatest contribution value of the Confirmation latent variable, that is Lecturer Services using multimedia learning is preferred, 3-the greatest contribution value of the Perceived Ease of Use latent variable that is teaching materials using multimedia learning is something that is easy for students to understand. This study also shows that : 4-the greatest contribution value of the Satisfaction latent variable that is multimedia learning used by Lecturer in teaching and learning in the classroom is able to provide information in accordance with the information that students need, and 5-the greatest contribution value of the Continued IT Usage Intention latent variable that is students interested in understanding the material, which is taught by Lecturer, if Lecturer teaching using multimedia based than conventional models.
\end{abstract}

Keywords - Perceived Usefulness; Perceived Ease of Use; Confirmation; Satisfaction dan Continued IT Usage Intention; Multimedia Learning.

\section{PENDAHULUAN}

Tantangan di dunia pendidikan adalah membangun masyarakat berpengetahuan (knowledge based society), dimana untuk membangunnya multimedia learning memainkan peranan yang sangat penting. Multimedia learning adalah pembelajaran yang memanfaatkan atau menerapkan teknologi informasi dan komunikasi [1]. Multimedia learning system yaitu sistem dengan menerapkan pembelajaran yang memberikan kebebasan para user untuk saling berhubungan dengan menggunakan berbagai media dan asset digital menggunakan media internet serta memanfaatkan audio visual (video, grafis dan teks) dalam kegiatan belajar mengajar.

Melalui multimedia learning, peserta didik dimungkinkan untuk tetap dapat belajar sekalipun secara fisik tidak hadir atau berhalangan hadir mengikuti kegiatan perkuliahan di dalam kelas. Keadaan yang demikian ini dapat terjadi apabila lembaga pendidikan telah mengembangkan dan mengimplementasikan multimedia learning dalam kegiatan pembelajaran sehingga para peserta didik dapat lebih mengoptimalkan kegiatan belajarnya. Interaksi para peserta didik dengan guru atau dosen tidak lagi terbatas hanya di ruang kelas saja atau perkuliahan, tetapi dapat dilanjutkan di ruang maya / virtual room [2].

Persepsi pemakai (user) yaitu mahasiswa dalam penggunaan multimedia learning akan sangat membantu dalam pemanfaatan teknologi informasi yang optimal. Istilah teknologi informasi seringkali rancu dengan istilah sistem informasi itu sendiri dan kadang menjadi bahan perdebatan. Ada yang menggunakan istilah teknologi informasi untuk menjabarkan sekumpulan sistem informasi, pemakai, dan manajemen [3]. Pernyataan tersebut menggambarkan bahwa teknologi informasi adalah bagian dari sistem informasi [4].

TAM (technology acceptance model) adalah salah satu model perilaku pemanfaatan teknologi informasi dimana dalam penelitian ini akan difokuskan pada pemanfaatan multimedia learning. Model ini menyediakan dasar teori untuk menelusuri faktor yang menjelaskan pemakaian software dan menghubungkannya dengan kinerja pemakai. Model ini dikemukakan oleh Davis yang mengembangkan kerangka pemikiran tentang minat pemanfaatan IT [5] dalam riset ini difokuskan pada multimedia learning. TAM berfokus pada sikap terhadap pemakaian multimedia learning oleh pemakai dengan mengembangkannya berdasarkan persepsi manfaat dan kemudahan dalam pemakaian multimedia learning.

Dalam pemanfaatan multimedia learning perlu dikaji indikator yang dominan dengan menggunakan Analisis konfirmatori atau sering disebut Confirmatory Factor Analysis (CFA) didesain untuk menguji multidimensionalitas dari suatu konstruk teoritis. Analisis ini sering juga disebut uji validitas 
suatu konstruk teoritis. Variabel laten yang digunakan dalam penelitian dibentuk berdasarkan konsep teoritis dengan beberapa indikator atau manifest. Analisis konfirmatori ingin menguji apakah indikator-indikator tersebut merupakan indikator yang valid sebagai pengukur konstruk laten. Dengan kata lain apakah indikator-indikator tersebut merupakan ukuran unidimensionalitas dari suatu konstruk laten [7]

\section{TINJAUAN PUSTAKA}

\section{A. Technology Acceptance Modelling (TAM)}

TAM (technology acceptance model) adalah salah satu model perilaku pemanfaatan teknologi informasi dimana dalam penelitian ini akan difokuskan pada pemanfaatan multimedia learning. Model ini menyediakan dasar teori untuk menelusuri faktor yang menjelaskan pemakaian software dan menghubungkannya dengan kinerja pemakai. Model ini dikemukakan oleh Davis yang mengembangkan kerangka pemikiran tentang minat pemanfaatan multimedia learning.

TAM berfokus pada sikap terhadap pemakaian multimedia learning oleh pemakai dengan mengembangkannya berdasarkan persepsi manfaat dan kemudahan dalam pemakaian multimedia learning. TAM merupakan satu di antara banyak model penelitian yang berpengaruh dalam studi determinan akseptasi multimedia learning. TAM banyak digunakan untuk memprediksi tingkat akseptasi pemakai (user acceptance) dan pemakaian yang berdasarkan persepsi terhadap kemudahan penggunaan multimedia learning. Implikasi akseptasi dapat dipelajari dengan menguji hubungan antara akseptasi teknologi informasi dan dampaknya kepada pemakai individual. Pemanfaatan teknologi berhubungan dengan cara organisasi merencanakan dan mengatur teknologi informasi dalam mencapai manfaat potensial dan efektif. Teknologi informasi diterapkan sesuai dengan strategi bisnis. Oleh karenanya, organisasi dapat mengadopsi berbagai tipe pemanfaatan teknologi tergantung pada strategi bisnisnya [8]. TAM mengacu pada model alternatif dari Reason Action Theory (TRA) dan Theory of Planned Behaviour (TPB) dalam konteks pemakai (user) dari teknologi informasi [9]. Beberapa faktor yang mempengaruhi pemanfaatan teknologi informasi yaitu pemanfaatan teknologi informasi dan kemudahan pemakaian teknologi informasi.

\section{B. Multimedia Learning}

Multimedia learning adalah bagian dari e-learning dengan pemanfaatan banyak teknologi dengan memanfaatkan media audio visual (video dan grafis) serta media teks dalam kegiatan belajar mengajar. Secara umum, teknologi e-learning dilakukan untuk mengatasi permasalahan yang berkaitan dengan pembelajaran tatap muka (konvensional) yang diminimalkan [10].

Multimedia adalah penggabungan beberapa media yang berbeda yang bertujuan untuk menyampaikan informasi dalam bentuk Text, Audio,Grafik, Animasi dan Video atau bisa juga di katakan kombinasi antara tiga elemen yaitu suara, gambar dan text.

\section{Confirmatory Factor Analysis (CFA)}

\section{Model umum CFA}

Analisis Faktor Konfirmatori merupakan salah satu metode analisis multivariat yang dapat digunakan untuk mengkonfirmasikan apakah model pengukuran yang dibangun sesuai dengan yang dihipotesiskan. Dalam analisis faktor konfirmatori, terdapat variabel laten dan variabel indikator. Variabel laten adalah variabel yang tidak dapat dibentuk dan dibangun secara langsung sedangkan variabel indikator adalah variabel yang dapat diamati dan diukur secara langsung [7]. Model umum analisis faktor konfirmatori adalah :

$$
\mathbf{x}=\boldsymbol{\Lambda} \boldsymbol{X} \boldsymbol{\xi}+\boldsymbol{\delta}
$$

\section{Keterangan:}

$\mathbf{x}$ merupakan vektor bagi peubah-peubah indikator berukuran q $\mathrm{x} 1$

$\boldsymbol{\Lambda} \boldsymbol{X}$ merupakan matriks bagi faktor loading atau koefisien yang menunjukan hubungan $\boldsymbol{x}$ dengan $\boldsymbol{\xi}$ berukuran q $\mathrm{x}$ n

$\xi(k s i)$, merupakan vektor bagi peubah-peubah laten berukuran $\mathrm{n} \times 1$

$\boldsymbol{\delta}$ vektor bagi galat pengukuran berukuran q x 1

\section{Convergent Validity}

Indikator suatu konstruk laten harus memiliki proporsi varian yang tinggi atau disebut convergent validity. Syarat (ambang batas atau threshold) yang harus dipenuhi berkisar antara 0,5 - 0,6 dan ambang batas idealnya 0,7 [7].

\section{Construct Reliability}

Reliabilitas juga merupakan salah satu indikator validitas convergent. Banyak juga yang menggunakan rumus alpha cronbach dalam pengujian reliabilitas walaupun kenyataannya alpha cronbach memberikan reliabilitas yang lebih rendah dibandingkan dengan construct reliability. Besarnya nilai construct reliability dapat dihitung dengan rumus sebagai berikut : [7]

$$
C R=\frac{\left[\sum_{i=1}^{n} \lambda i\right]^{2}}{\left[\sum_{i=1}^{n} \lambda i\right]^{2}+\left[\sum_{i=1}^{n} \delta i\right]}
$$

Construct reliability 0,7 atau lebih menunjukkan reliabilitas yang baik, sedangkan reliabilitas $0,6-0,7$ masih dapat diterima dengan syarat validitas indikator dalam model baik [7].

\section{METODE PENELITIAN}

\section{A. Pengukuan Variabel Laten dan Manifest}

1. Penggunaan TI (Perceived Usefulness)

Perceived usefulness didefinisikan sebagai tingkat dimana seseorang percaya bahwa dengan menggunakan multimedia learning dapat meningkatkan kinerja . Variabel laten Perceived 
usefulness terdiri dari 5 variabel observasi (indicator) dengan menggunakan skala Likert point 5 yang diadopsi dari penelitian [11].

\begin{tabular}{cl} 
Indikator & \multicolumn{1}{c}{ Indikator } \\
$\mathrm{X} 1=$ & $\begin{array}{l}\text { Menggunakan multimedia learning dalam model } \\
\text { pembelajaran di kelas meningkatkan produktivitas } \\
\text { saya dalam belajar. } \\
\text { Xenggunakan multimedia learning memungkinkan } \\
\text { saya belajar lebih giat. } \\
\text { X3 }=\end{array}$ \\
Xultimedia learning sangat berguna bagi saya \\
dalam proses belajar mengajar di kelas.
\end{tabular}

\section{Konfirmasi Pemakai (Confirmation)}

Konfirmasi pemakai TI dapat didefinisikan sebagai sebuah penegasan tentang harapan dan kepuasan yang dirasakan dalam penggunaan multimedia learning, sehingga menjadi penegasan bagi pemakai untuk ditindaklanjuti organisasi [12]. Variabel laten Confirmation terdiri dari 3 variabel observasi (indicator) dengan menggunakan skala Likert point 5 yang diadopsi dari penelitian [11].

\begin{tabular}{|c|c|}
\hline Indikator & Indikator \\
\hline $\mathrm{X} 6=$ & $\begin{array}{l}\text { Pengalaman saya dalam menyerap materi berbasis } \\
\text { multimedia learning dari Dosen-dosen saya telah } \\
\text { sesuai harapan saya dibandingkan model } \\
\text { pembelajaran yang konvensional dengan digital } \\
\text { media yang minim. }\end{array}$ \\
\hline $\mathrm{X} 7=$ & $\begin{array}{l}\text { Pelayanan Dosen dengan menggunakan multimedia } \\
\text { learning lebih saya sukai. }\end{array}$ \\
\hline$X 8=$ & $\begin{array}{l}\text { Secara keseluruhan, saya lebih mengharapkan } \\
\text { apabila Dosen menggunakan berbagai media } \\
\text { (multimedia) dalam proses belajar mengajar di } \\
\text { kelas. }\end{array}$ \\
\hline
\end{tabular}

3. Kemudahan dalam Penggunaan TI (Perceived Ease of Use)

Perceived ease of use didefinisikan Davis et al. [6] merupakan seberapa besar teknologi komputer dirasakan relatif mudah untuk dipahami dan digunakan. Variabel laten Perceived Ease of Use terdiri dari 5 variabel observasi (indicator) dengan menggunakan skala Likert point 5 yang diadopsi dari penelitian [11].

\begin{tabular}{cl} 
Indikator & \multicolumn{3}{c}{ Indikator } \\
X9 $=$ & $\begin{array}{l}\text { Jika pembelajaran materi kuliah menggunakan } \\
\text { multimedia learning, bagi saya tidaklah perlu } \\
\text { menghabiskan waktu yang lama untuk memahami } \\
\text { materi yang diajarkan dosen. }\end{array}$ \\
X10 $=$ & $\begin{array}{l}\text { Materi kuliah dengan menggunakan multimedia } \\
\text { learning adalah sesuatu yang mudah bagi saya } \\
\text { untuk memahaminya. }\end{array}$ \\
$\mathrm{X} 11=$ & $\begin{array}{l}\text { Mudah bagi saya untuk mengingat tentang materi } \\
\text { yang diajarkan menggunakan multimedia learning. } \\
\text { X12 }=\end{array}$ \\
Multimedia learning sangat fleksibel dalam \\
penggunaannya. \\
Mudah bagi saya untuk trampil dalam menggunakan \\
multimedia learning.
\end{tabular}

\section{Kepuasan Pemakai TI (Satisfaction)}

Kepuasan pemakai akhir (end-user) terhadap sistem informasi adalah bagaimana cara pemakai memandang multimedia learning secara nyata, bukan pada kualitas multimedia learning secara teknik [13]. Variabel laten Satisfaction terdiri dari 5 variabel observasi (indicator) dengan menggunakan skala Likert point 5 yang diadopsi dari penelitian [11].

\begin{tabular}{|c|c|}
\hline Indikator & Indikator \\
\hline $\mathrm{Y} 1=$ & $\begin{array}{l}\text { Pembelajaran dengan multimedia learning mampu } \\
\text { memberikan informasi atau materi persis seperti } \\
\text { yang saya harapkan. }\end{array}$ \\
\hline $\mathrm{Y} 2=$ & $\begin{array}{l}\text { Dengan pembelajaran multimedia learning yang } \\
\text { dilakukan Dosen menurut saya telah mampu } \\
\text { menghasilkan informasi yang cukup baik kepada } \\
\text { mahasiswa. }\end{array}$ \\
\hline $\mathrm{Y} 3=$ & $\begin{array}{l}\text { Multimedia learning yang digunakan Dosen dalam } \\
\text { proses belajar mengajar di kelas mampu } \\
\text { memberikan informasi sesuai dengan informasi } \\
\text { yang dibutuhkan mahasiswa. }\end{array}$ \\
\hline $\mathrm{Y} 4=$ & $\begin{array}{l}\text { Saya dapat memperoleh informasi yang saya } \\
\text { butuhkan cepat dengan pembelajaran multimedia } \\
\text { learning yang disampaikan Dosen. }\end{array}$ \\
\hline $\mathrm{Y} 5=$ & $\begin{array}{l}\text { Model pembelajaran multimedia learning yang } \\
\text { digunakan Dosen mampu mentransfer pengetahuan } \\
\text { atau ilmu (transfer knowledge) yang akurat dan } \\
\text { mutakhir/up to date. }\end{array}$ \\
\hline
\end{tabular}

5. Minat Pemanfaatan TI (Continued IT Usage Intention)

Minat pemanfaatan teknologi berhubungan dengan cara perusahaan merencanakan dan mengatur teknologi informasi dalam mencapai manfaat potensial dan efektif [8]. Teknologi informasi diterapkan sesuai dengan strategi bisnis. Oleh karenanya, perusahaan dapat mengadopsi berbagai tipe pemanfaatan teknologi tergantung pada strategi bisnisnya. Variabel laten Continued IT Usage Intention terdiri dari 3 variabel observasi (indicator) dengan menggunakan skala Likert point 5 yang diadopsi dari penelitian [11]

\begin{tabular}{|c|c|}
\hline Indikator & Indikator \\
\hline $\mathrm{Y} 6=$ & $\begin{array}{l}\text { Saya berminat untuk memahami materi yang } \\
\text { diajarkan Dosen saya jika Dosen mengajar berbasis } \\
\text { multimedia learning dibandingkan model } \\
\text { konvensional (ceramah dan tanya jawab tanpa } \\
\text { media digital). }\end{array}$ \\
\hline $\mathrm{Y} 7=$ & $\begin{array}{l}\text { Menurut saya pembelajaran dengan multimedia } \\
\text { learning adalah salah satu aktivitas pembelajaran } \\
\text { yang efisien dan efektif. }\end{array}$ \\
\hline $\mathrm{Y} 8=$ & $\begin{array}{l}\text { Saya lebih memperhatikan pembelajaran } \\
\text { multimedia learning daripada proses } \\
\text { pembelajaran manual tanpa menggunakan } \\
\text { teknologi informasi. }\end{array}$ \\
\hline
\end{tabular}

\section{B. Populasi dan Sampel}

- Populasi diperoleh dari target responden yaitu Perguruan Tinggi Swasta di kota Semarang yang sudah menerapkan pembelajaran jarak jauh berkonsep multimedia learning.

- Sampel dilakukan dengan menggunakan teknik judgement area sampling yaitu teknik sampling yang didasarkan atas penetapan wilayah penelitian yaitu 4 
perguruan tinggi swasta di Semarang yang disebarkan yaitu : 1 PTS wilayah Semarang Selatan, 1 PTS wilayah Semarang Barat, 1 PTS wilayah Semarang Timur dan 1 PTS wilayah Semarang Utara, sehingga jumlah responden secara keseluruhan sebanyak 200 responden yaitu mahasiswa.

\section{Langkah Analisis}

1. Pengujian unidimensionalitas setiap variabel laten dengan menggunakan Confirmatory Factor Analysis (CFA).

2. Menduga parameter model dengan metode kemungkinan maksimum

3. Melakukan uji kecocokan model (Goodness of Fit Model)

4. Uji Validitas dan Reliabilitas

\section{ANALISIS DAN PEMBAHASAN}

\section{A. Tanggapan Responden tentang Pemanfaatan Multimedia Learning}

Hasil penyebaran kuesioner menunjukkan tentang tanggapan tentang Daya Guna Multimedia Learning (Perceived Usefullness) mengindikasikan mayoritas mahasiswa pada perguruan tinggi di kota Semarang sudah menggunakan multimedia learning dalam model pembelajaran di kelas meningkatkan produktivitas mahasiswa dalam belajar, menurut mahasiswa menggunakan multimedia learning dalam model pembelajaran di kelas memungkinkan mahasiswa belajar lebih giat, dan mahasiswa berpendapat bahwa multimedia learning sangat berguna dan efektif bagi mahasiswa dalam proses belajar mengajar di kelas.

Tanggapan mahasiswa dalam hal konfirmasi penggunaan multimedia learning (confirmation) menunjukkan bahwa : pengalaman dalam menyerap materi berbasis multimedia learning dari dosen-dosen telah sesuai harapan mahasiswa dibandingkan model pembelajaran yang konvensional dengan digital media yang minim, pelayanan Dosen dengan menggunakan multimedia learning lebih disukai mahasiswa dan mahasiswa lebih mengharapkan apabila Dosen menggunakan berbagai media (multimedia) dalam proses belajar mengajar di kelas.

Tanggapan mahasiswa berkaitan dengan Kemudahan Penggunaan Multimedia Learning (Perceived Ease Of Use) yaitu sebagian besar mahasiswa berpendapat jika pembelajaran materi kuliah menggunakan multimedia learning, bagi mahasiswa tidaklah perlu menghabiskan waktu yang lama untuk memahami materi yang diajarkan dosen, mahasiswa berpendapat bahwa materi kuliah dengan menggunakan multimedia learning adalah sesuatu yang mudah bagi mahasiswa untuk memahaminya dan mudah bagi mahasiswa untuk mengingat tentang materi yang diajarkan menggunakan multimedia learning, multimedia learning sangat fleksibel dalam penggunaannya dan mudah bagi mahasiswa untuk trampil dalam menggunakan multimedia learning.
Tanggapan mahasiswa mengenai Kepuasan (User Satisfaction) atas pembelajaran multimedia di kampus menunjukkan bahwa pembelajaran dengan multimedia learning mampu memberikan informasi atau materi persis seperti yang diharapkan, dengan pembelajaran multimedia learning yang dilakukan Dosen menurut mahasiswa telah mampu menghasilkan informasi yang cukup baik kepada mahasiswa, multimedia learning yang digunakan Dosen dalam proses belajar mengajar di kelas mampu memberikan informasi sesuai dengan informasi yang dibutuhkan mahasiswa, mahasiswa dapat memperoleh informasi yang dibutuhkan cepat dengan pembelajaran multimedia learning yang disampaikan Dosen dan Model pembelajaran multimedia learning yang digunakan Dosen mampu mentransfer pengetahuan atau ilmu (transfer knowledge) yang akurat dan mutakhir/up to date.

Tanggapan mahasiswa berkaitan dengan Minat Pemanfaatan Teknologi Informasi (Continued IT Usage Intention) atas pembelajaran multimedia di kampus menunjukkan bahwa mahasiswa berminat untuk memahami materi yang diajarkan Dosen, jika Dosen mengajar berbasis multimedia learning dibandingkan model konvensional (ceramah dan tanya jawab tanpa media digital), pembelajaran dengan multimedia learning adalah salah satu aktivitas pembelajaran yang efisien dan efektif, dan mahasiswa lebih memperhatikan pembelajaran multimedia learning daripada proses pembelajaran manual tanpa menggunakan teknologi informasi

\section{B. Pengujian $\boldsymbol{C F A}$}

1. Uji Unidimensional Variabel Laten Perceived Usefulness

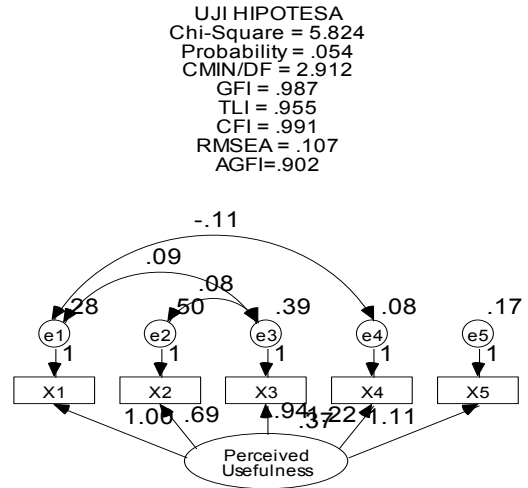

Gambar di atas menunjukkan bahwa nilai goodness of fit Perceived Usefulness sebagai berikut:

Tabel 1

Uji Goodness of Fit Variabel Laten Perceived Usefulness

\begin{tabular}{|c|c|c|c|}
\hline $\begin{array}{c}\text { Goodness of Fit } \\
\text { Indeks }\end{array}$ & $\begin{array}{c}\text { Cut off } \\
\text { Value }\end{array}$ & Hasil & $\begin{array}{c}\text { Evaluasi } \\
\text { Model }\end{array}$ \\
\hline Chi - Square & Kecil & 5,824 & Fit \\
\hline Probability & $\geq 0,05$ & 0,054 & Fit \\
\hline CMIN/DF & $\leq 2,00$ & 2,912 & Moderate \\
\hline TLI & $\geq 0,95$ & 0,955 & Fit \\
\hline CFI & $\geq 0,95$ & 0,991 & Fit \\
\hline RMSEA & $\leq 0,08$ & 0,107 & Moderate \\
\hline
\end{tabular}


Pada Tabel 1 menjelaskan nilai Goodness of fit yang sudah dimodifikasi menghasilkan nilai probability 0,054 dan nilai uji kesesuaian yang lain seperti CMIN/DF, TLI, CFI dan RMSEA memenuhi kriteria fit sehingga dapat dikatakan model dapat diterima dan langkah selanjutnya adalah uji reliabilitas. Nilai Construct Reliability variabel Perceived Usefulness adalah 0,613. Sehingga variabel laten Perceived Usefulness dikatakan memiliki reliabilitas yang baik karena nilai CR lebih dari 0,6.

Langkah selanjutnya adalah mengetahui nilai kontribusi terbesar, dalam model variabel laten Perceived Usefulness masing-masing indikator memberikan nilai kontribusi yang dapat dilihat pada tabel berikut :

Tabel 2

Kotribusi (CFA) Variabel Perceived Usefulness

\begin{tabular}{|c|c|c|c|}
\hline Hubungan & Estimasi & $\overline{\mathrm{R}^{2}}$ & Keterangan \\
\hline $\begin{array}{c}\text { X1 <--- Perceived } \\
\text { Usefulness }\end{array}$ & 0.751 & 0.564 & \multirow{5}{*}{$\begin{array}{c}\text { Indikator X4 } \\
\text { (Menggunakan } \\
\text { multimedia } \\
\text { learning } \\
\text { meningkatkan } \\
\text { efektivitas dalam } \\
\text { pembelajaran di } \\
\text { kelas) yang paling } \\
\text { dominan }\end{array}$} \\
\hline $\begin{array}{c}\mathrm{X} 2<--- \text { Perceived } \\
\text { Usefulness }\end{array}$ & 0.511 & 0.261 & \\
\hline $\begin{array}{c}\text { X3 <--- Perceived } \\
\text { Usefulness }\end{array}$ & 0.674 & 0.454 & \\
\hline $\begin{array}{c}\text { X4 <--- Perceived } \\
\text { Usefulness }\end{array}$ & 0.933 & 0.870 & \\
\hline $\begin{array}{c}\text { X5 <--- Perceived } \\
\text { Usefulness }\end{array}$ & 0.851 & 0.724 & \\
\hline
\end{tabular}

2. Uji Unidimensional Variabel Laten Confirmation

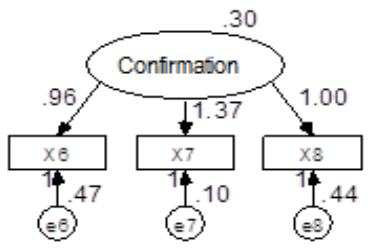

Dari gambar di atas menunjukkan bahwa variabel laten Confirmation hanya terdiri dari 3 indikator sehingga tidak bisa dikaji nilai goodness of fit. Nilai Construct Reliability variabel Confirmation adalah 0,615 . Sehingga variabel laten Confirmation dikatakan memiliki reliabilitas yang baik karena nilai CR lebih dari 0,6 .

Langkah selanjutnya adalah mengetahui nilai kontribusi terbesar, dalam model variabel laten Confirmation masing-masing indikator memberikan nilai kontribusi yang dapat dilihat pada tabel berikut :

Tabel 3

Kotribusi (CFA) Variabel Confirmation

\begin{tabular}{|c|c|c|c|}
\hline Hubungan & Estimasi & $\mathrm{R}^{2}$ & \multirow{4}{*}{$\begin{array}{c}\text { Keterangan } \\
\text { Indikator X7 } \\
\text { (Pelayanan Dosen } \\
\text { dengan } \\
\text { menggunakan } \\
\text { multimedia learning } \\
\text { lebih disukai) yang } \\
\text { paling dominan }\end{array}$} \\
\hline $\begin{array}{c}\text { X6<--- } \\
\text { Confirmation }\end{array}$ & 0.636 & 0.404 & \\
\hline $\begin{array}{c}\text { X7 <--- } \\
\text { Confirmation }\end{array}$ & 0.922 & 0.850 & \\
\hline $\begin{array}{c}\text { X8 <--- } \\
\text { Confirmation }\end{array}$ & 0.611 & 0.373 & \\
\hline
\end{tabular}

3. Uji Unidimensional Variabel Perceived Ease of Use
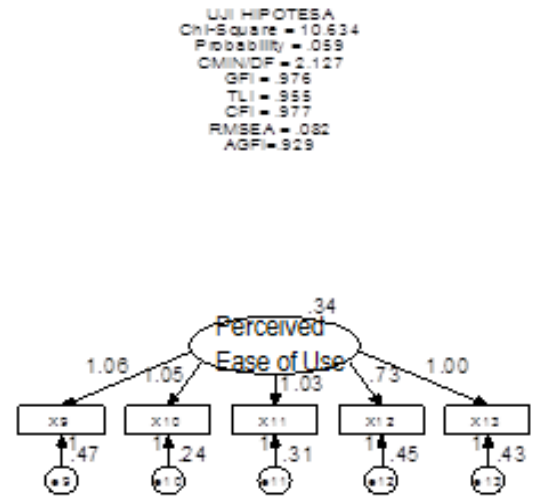

Dari gambar di atas menunjukkan bahwa variabel laten Perceived Ease of Use memiliki nilai goodness of fit dengan tampilan sebagai berikut :

$$
\text { Tabel } 4
$$

Uji Goodness of Fit Variabel Laten Perceived Ease of Use

\begin{tabular}{|c|c|c|c|}
\hline $\begin{array}{c}\text { Goodness of Fit } \\
\text { Indeks }\end{array}$ & $\begin{array}{c}\text { Cut off } \\
\text { Value }\end{array}$ & Hasil & $\begin{array}{c}\text { Evaluasi } \\
\text { Model }\end{array}$ \\
\hline Chi - Square & Kecil & 10,634 & Fit \\
\hline Probability & $\geq 0,05$ & 0,059 & Fit \\
\hline CMIN/DF & $\leq 2,00$ & 2,127 & Moderate \\
\hline TLI & $\geq 0,95$ & 0,976 & Fit \\
\hline CFI & $\geq 0,95$ & 0,955 & Fit \\
\hline RMSEA & $\leq 0,08$ & 0,082 & Moderate \\
\hline AGFI & $\geq 0,90$ & 0,929 & Fit \\
\hline
\end{tabular}

Nilai Goodness of fit menghasilkan nilai probability 0,059 dan nilai uji kesesuaian yang lain seperti CMIN/DF, TLI, CFI dan RMSEA memenuhi kriteria fit sehingga dapat dikatakan model dapat diterima dan langkah selanjutnya adalah uji reliabilitas. Nilai Construct Reliability variabel Perceived Ease of Use adalah 0,689. Sehingga variabel laten Perceived Ease of Use dikatakan memiliki reliabilitas yang baik karena nilai CR lebih dari 0,6.

Langkah selanjutnya adalah mengetahui nilai kontribusi terbesar, dalam model variabel laten Perceived Ease of Use masing-masing indikator memberikan nilai kontribusi yang dapat dilihat pada tabel berikut :

Tabel 5

Kotribusi (CFA) Variabel Ease of Use

\begin{tabular}{|c|c|c|c|}
\hline Hubungan & Estimasi & $\mathrm{R}^{2}$ & Keterangan \\
\hline $\begin{array}{c}\mathrm{X} 9 \text { <--- Perceived } \\
\text { Ease of Use }\end{array}$ & 0.670 & 0.449 & $\begin{array}{l}\text { Indikator X10 } \\
\text { (Materi kuliah }\end{array}$ \\
\hline $\begin{array}{c}\mathrm{X} 10<--- \text { Perceived } \\
\text { Ease of Use }\end{array}$ & 0.781 & 0.610 & $\begin{array}{c}\text { dengan } \\
\text { menggunakan }\end{array}$ \\
\hline $\begin{array}{c}\text { X11 <--- Perceived } \\
\text { Ease of Use }\end{array}$ & 0.733 & 0.537 & $\begin{array}{c}\text { multimedia } \\
\text { learning adalah }\end{array}$ \\
\hline $\begin{array}{c}\mathrm{X} 12<--- \text { Perceived } \\
\text { Ease of Use }\end{array}$ & 0.535 & 0.286 & $\begin{array}{l}\text { sesuatu yang } \\
\text { mudah bagi }\end{array}$ \\
\hline $\begin{array}{c}\mathrm{X} 13<--- \text { Perceived } \\
\text { Ease of Use }\end{array}$ & 0.663 & 0.440 & $\begin{array}{c}\text { memahaminya) } \\
\text { yang paling } \\
\text { dominan }\end{array}$ \\
\hline
\end{tabular}


4. Uji Unidimensional Variabel Laten Satisfaction
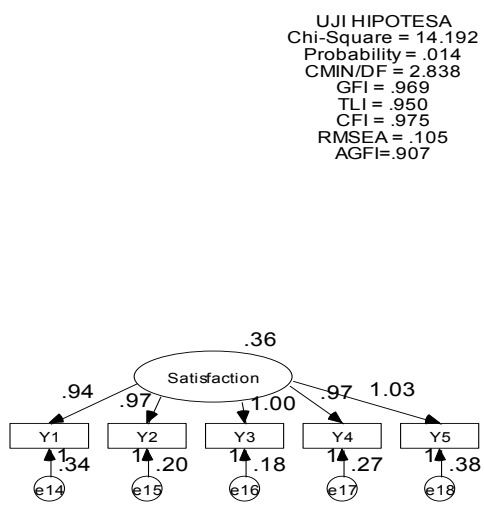

Dari gambar di atas menunjukkan bahwa variabel laten Satisfaction memiliki nilai goodness of fit dengan tampilan sebagai berikut :

Tabel 6

Uji Goodness of Fit Variabel Laten Satisfaction

\begin{tabular}{|c|c|c|c|}
\hline $\begin{array}{c}\text { Goodness of Fit } \\
\text { Indeks }\end{array}$ & $\begin{array}{c}\text { Cut off } \\
\text { Value }\end{array}$ & Hasil & $\begin{array}{c}\text { Evaluasi } \\
\text { Model }\end{array}$ \\
\hline Chi - Square & Kecil & 14,192 & Moderate \\
\hline Probability & $\geq 0,05$ & 0,014 & Moderate \\
\hline CMIN/DF & $\leq 2,00$ & 2,838 & Moderate \\
\hline TLI & $\geq 0,95$ & 0,950 & Fit \\
\hline CFI & $\geq 0,95$ & 0,975 & Moderate \\
\hline RMSEA & $\leq 0,08$ & 0,105 & Moderate \\
\hline AGFI & $\geq 0,90$ & 0,907 & Fit \\
\hline
\end{tabular}

Nilai Goodness of fit menghasilkan nilai probability 0,014 dan nilai uji kesesuaian yang lain seperti CMIN/DF, TLI, CFI dan RMSEA memenuhi kriteria cukup fit (moderate) sehingga dapat dikatakan model dapat diterima dan langkah selanjutnya adalah uji reliabilitas. Nilai Construct Reliability variabel Satisfaction adalah 0,633. Sehingga variabel laten Satisfaction dikatakan memiliki reliabilitas yang baik karena nilai CR lebih dari 0,6.

Langkah selanjutnya adalah mengetahui nilai kontribusi terbesar, dalam model variabel laten Satisfaction masing-masing indikator memberikan nilai kontribusi yang dapat dilihat pada tabel berikut :

Tabel 7

Kotribusi (CFA) Variabel Satisfaction

\begin{tabular}{|c|c|c|c|}
\hline Hubungan & Estimasi & $\mathrm{R}^{2}$ & Keterangan \\
\hline $\begin{array}{c}\text { Y1<--- } \\
\text { Satisfaction }\end{array}$ & 0.696 & 0.484 & $\begin{array}{c}\text { Indikator Y3 } \\
\text { (Multimedia learning }\end{array}$ \\
\hline $\begin{array}{c}\text { Y2<--- } \\
\text { Satisfaction }\end{array}$ & 0.792 & 0.627 & $\begin{array}{l}\text { yang digunakan Dosen } \\
\text { dalam proses belajar }\end{array}$ \\
\hline $\begin{array}{c}\text { Y3<--- } \\
\text { Satisfaction }\end{array}$ & 0.816 & 0.666 & $\begin{array}{l}\text { mengajar di kelas } \\
\text { mampu memberikan }\end{array}$ \\
\hline $\begin{array}{c}\text { Y4<--- } \\
\text { Satisfaction }\end{array}$ & 0.745 & 0.555 & $\begin{array}{c}\text { informasi sesuai } \\
\text { dengan informasi yang }\end{array}$ \\
\hline $\begin{array}{c}\text { Y5<--- } \\
\text { Satisfaction }\end{array}$ & 0.707 & 0.500 & $\begin{array}{c}\text { dibutuhkan mahasiswa) } \\
\text { yang paling dominan }\end{array}$ \\
\hline
\end{tabular}

5. Uji Unidimensional Variabel Laten Continued IT Usage Intention

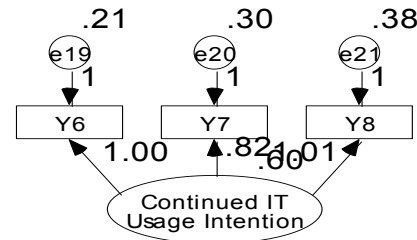

Dari gambar di atas menunjukkan bahwa variabel laten Continued IT Usage Intention hanya terdiri dari 3 indikator sehingga tidak bisa dikaji nilai goodness of fit. Nilai Construct Reliability variabel Continued IT Usage Intention adalah 0,650. Sehingga variabel laten Continued IT Usage Intention dikatakan memiliki reliabilitas yang baik karena nilai CR lebih dari 0,6.

Langkah selanjutnya adalah mengetahui nilai kontribusi terbesar, dalam model variabel laten Continued IT Usage Intention masing-masing indikator memberikan nilai kontribusi yang dapat dilihat pada tabel berikut :

Tabel 8

Kotribusi (CFA) Variabel Continued IT Usage Intention

\begin{tabular}{|c|c|c|c|}
\hline Hubungan & Estimasi & $\mathrm{R}^{2}$ & Keterangan \\
\hline $\begin{array}{c}\text { Y6<--- } \\
\text { Continued IT } \\
\text { Usage Intention }\end{array}$ & 0.864 & 0.746 & $\begin{array}{c}\text { Indikator Y6 } \\
\text { (mahasiswa berminat } \\
\text { untuk memahami }\end{array}$ \\
\hline $\begin{array}{c}\text { Y7<--- } \\
\text { Continued IT } \\
\text { Usage Intention }\end{array}$ & 0.757 & 0.573 & $\begin{array}{c}\text { materi yang diajarkan } \\
\text { Dosen saya jika Dosen } \\
\text { mengajar berbasis }\end{array}$ \\
\hline $\begin{array}{c}\text { Y8<--- } \\
\text { Continued IT } \\
\text { Usage Intention }\end{array}$ & 0.783 & 0.613 & $\begin{array}{c}\text { multimedia learning } \\
\text { dibandingkan model } \\
\text { konvensional } \\
\text { (ceramah dan tanya } \\
\text { jawab tanpa media } \\
\text { digital)) yang paling } \\
\text { dominan }\end{array}$ \\
\hline
\end{tabular}

\section{KESIMPULAN}

Dari hasil penelitian menggunakan confirmatory factor analysis menunjukkan bahwa (1) nilai kontribusi terbesar variabel laten Perceived Usefulness pada Indikator X4 yaitu multimedia learning meningkatkan efektivitas dalam pembelajaran di kelas, (2) nilai kontribusi terbesar variabel laten Confirmation pada Indikator X7 yaitu Pelayanan Dosen dengan menggunakan multimedia learning lebih disukai, (3) nilai kontribusi terbesar variabel laten Perceived Ease of Use pada indikator X10 Materi kuliah dengan menggunakan multimedia learning adalah sesuatu yang mudah bagi mahasiswa untuk memahaminya, (4) nilai kontribusi terbesar variabel laten Satisfaction pada indikator Y3 yaitu Multimedia learning yang digunakan Dosen dalam proses belajar mengajar di kelas mampu memberikan informasi sesuai dengan informasi yang dibutuhkan mahasiswa dan (5) nilai kontribusi terbesar variabel laten Continued IT Usage Intention pada indikator Y6 yaitu mahasiswa berminat untuk memahami materi yang diajarkan Dosen, jika Dosen mengajar berbasis multimedia 
learning dibandingkan model konvensional (ceramah dan tanya jawab tanpa media digital).

Saran penelitian ini masih terbatas pada mahasiswa di kota Semarang yang mengikuti perkuliahan dan mengikuti pembelajaran berbasis multimedia learning pada mata kuliah CISCO dan ORACLE. Penelitian tidak secara spesifik dalam pengambilan sampel yaitu praktisi yang lebih berpengalaman di bidang IT khususnya praktisi multimedia. Batasan yang lain yaitu penelitian hanya mengkaji sampai dengan tahap confirmatory factor analysis sehingga untuk penelitian selanjutnya perlu memperdalam kajian tentang komputasi stuctural equation modelling yang berbasis pada CFA dan regresi.

\section{REFERENSI}

[1] Chaeruman, Uwes a., 2008. Mendorong Penerapan e-learning di Sekolah. Jurnal Teknodik Vol. XII No. 1 Juni 2008.

[2] Siahaan, Sudirman. 2008. Mengapa Harus Menggunakan E-Learning dalam Kegiatan Pembelajaran. Jurnal Teknodik Vol. XII No. 1 Juni 2008 .

[3] Turban, Efraim, McLean Ephraim, dan Wetherbe, James, 1999. Information Technology for Management Making Coinnections for Strategies Advantage, 2nd Edition, John Wiley and Sons Inc.

[4] Alter, Steven, 1992. Information System: A Management Perspective. The Benjamin Publishing Company Inc.

[5] Davis, F.D., 1986. A technology acceptance model for empirically testing new end-user information systems: theory and results, Doctoral dissertation, Sloan School of Management, Journal of MIT.

[6] Davis, F.D., R.P. Bagozzi, P.R. Warshaw, 1989. User acceptance of computer technology: a comparison of two theoretical models, Management Science 35 (8) 982-1003.

[7] Ghozali, I, 2008. Model Persamaan Struktural, Konsep dan Aplikasi dengan Program AMOS 16., Badan Penerbit UNDIP, Semarang.

[8] Croteau, Anne Marie, dan Bergeron, F., April 2001, "An information technology trilogy: business strategy, technological deployment and organizational performance," Journal of Strategic Information Systems, hlm. 77-99.

[9] Mathieson, K. (1991), "Predicting user intentions: comparing the technology acceptance model with the theory of planned behavior", Information Systems Research, Vol. 3 No. 3, pp. 173-91.

[10] Varlamis, Iraklis \& Apostolakis, Ioannis, 2006. The Present a nd Future of Standards for E-Learning Technologies. Interdisciplinary Journal of Knowledge and Learning Objects Volume 2

[11] Hong, Se-Joon, Thong, James Y.L. dan Tam, Kar Yan, 2006. Understanding continued information technology usage behavior: A comparison of three models in the context of mobile internet. Jurnal Elsevier 42; 1819-1834

[12] Bhattacherjee, A., 2001. An empirical analysis of the antecedents of electronic commerce service continuance, Jurnal Elsevier Decision Support Systems, 2; 201-214.

[13] Guimaraes, Staples dan Mckeen, 2003. Empirically Testing Some Main User Related Factor for System Development. Information and Management Amsterdam 38 No. 4. 